http://jmscr.igmpublication.org/home/ ISSN (e)-2347-176x ISSN (p) 2455-0450

crossref DOI: https://dx.doi.org/10.18535/jmscr/v9i4.10

\title{
Assessment of challenges faced by Health Care Workers caring COVID-19 patients at Level-3 COVID-19 Hospital
}

\author{
Authors \\ Imran Ahmed Khan', DK Srivastava ${ }^{2}$, Shardha Misra ${ }^{3}$ \\ ${ }^{1}$ Resident second year, ${ }^{2}$ Professor and Head, ${ }^{3}$ Assistant Professor, \\ Department of Community Medicine, BRD Medical College, Gorakhpur, UP, India \\ *Corresponding Author \\ Dr Rahmat Ali (Ms (ortho), MCh (ortho) ) \& Fellowship in Spine ${ }^{4}$ \\ Professor and H.O.D (Ortho Department), Maharishi Vashishtha Autonomous State Medical College, \\ Basti, UP, India
}

\begin{abstract}
Background: Health care workers including Doctors, Nurses, technicians and support staff are the main hands through which routine and urgent care are delivered to the people. Very little attention has been paid about the need to protect those who provided medical care; the entire focus was on the patient. The Covid 19 has affected healthcare workers badly all over the world. Front line health care providers have mortality rate of $1.4 \%$ but in countries like Italy it has gone up to 9\%. Given the boundless transmission of SARS-CoV-2 and reports of its spread to health care service providers, health care professionals are at high risk and can become potential bearers of the infection. COVID-19 outbreak came up with various lifethreatening issues along with certain other problems involving public, administrative and healthcare sector concerns. HCWs are there to treat but their views should be considered and addressed. This online survey highlights about the various issues and challenges faced by Health care workers especially front-line healthcare workers.

Objectives: To assess various concerns and challenges of HCWs during COVID-19 Pandemic and effect of this pandemic on the HCWs.

Materials and Methods: A cross sectional, on-line survey using Google form has been carried out at Level3 COVID-19 Hospital, Baba Raghav Das medical College Gorakhpur. A semi-structured predesigned and pretested questionnaire was used to collect the relevant data.

Results: A total of $219 \mathrm{HCWs}$ participated in the study, $90 \%$ of the respondents feared contracting COVID19 infection, and 97\% feared carrying the infection home. $80 \%$ respondents felt that they were not welcomed by their community.

Conclusion: Finding of this study revealed various areas which need improvement to tackle the scenario more efficiently as well as safeguarding health of healthcare workers.
\end{abstract}

\section{Introduction}

Viral outbreaks and pandemics have occurred regularly in past as SARS, MERS, H1N1 etc. They exposed health system challenges in responding to overwhelming levels of morbidity and mortality.COVID-19 outbreak came up with various life-threatening issues along with certain other problems involving public, administrative 
and healthcare sector concerns. The disease which was started from Wuhan, China soon spread across the globe very rapidly. In spite of warning messages, the response by global health community and policy makers were slow. ${ }^{1}$ The high surge in the number of cases worldwide led the WHO to declare it as public health emergency on January 30, 2020 where the overall mortality rate was 3.4\%. ${ }^{2,3}$ On March 11, 2020, WHO made the assessment and declared COVID-19 a pandemic. ${ }^{4}$ Healthcare workers are working day and night just to protect the citizens despite being at high-risk of exposure and they are being aimed by the virus. Not only this, but they are being brutally harassed by the patients themselves and their attendants. Social, economic, psychiatric and many other factors are responsible for deteriorating the health of these frontline healthcare workers. Given the boundless transmission of SARS-CoV-2 and reports of its spread to health care providers, they are at high risk and can become potential bearers of the infection. These risks include patient examination, surgical interventions and proximity of the health care provider to the patient. So, if adequate precautions are not taken it can potentially expose patients as well as health care providers to cross infection. Every time a HCW falls ill it puts more pressure on already strained health system. Front line health care providers have mortality rate of $1.4 \%$.but in countries like Italy it has gone up to 9\%. ${ }^{\mathbf{5}}$ According to the study by Kapoor et al, case fatality rate of $16.7 \%$ among Indian doctors, which was ten times the CFR of $1.7 \%$ in the general population. Among the practicing doctors, after excluding the resident doctors and house surgeons, the CFR was $36.4 \%$, which is almost 22 times more than what was seen in general population of India. ${ }^{6}$ The various challenges faced by health care workers include hazards like more prone to pathogen exposure, long working hours, psychological distress, fatigue, occupational burnout, stigma, and physical and psychological violence. This outbreak is a unique and unprecedented scenario for most of the health workers and their families too. This is a long-term fight and requires sustained response. ${ }^{7}$ Doctors are there to treat but their views should be considered and addressed. So, this online survey was planned to highlight about the various issues and challenges faced by Health care workers especially front-line healthcare workers. The Objective of this survey is to assess various concerns and challenges of HCWs during COVID-19 pandemic and to find out effect of this pandemic on the health of healthcare workers and finally drawing recommendations to manage those challenges.

\section{Materials and Methods}

A cross sectional, on-line survey using google form was carried out at Level-3 COVID-19 Hospital, Baba Raghav Das medical College Gorakhpur among Faculty, Resident doctors and nurses after obtaining their consent.

\section{Study Tools}

Pre-Phrased, semi-structured Questionnaire was designed based on the literature on the similar study and discussion with HCWs appointed on COVID-19 duty in consultation with the principal investigator \& co investigator to find out challenges faced by HCWs while caring for COVID-19 patients at Level-3 COVID-19 hospital. The questionnaire was framed to collect information on demography, type of $\mathrm{HCW}$, specialty etc. Survey questions included concerns of HCWs while taking care of COVID-19 patients, problems faced during their duty and effects on their routine life.

\section{Methodology}

An online survey was conducted among faculty, residents of and nurses of Level-3 COVID-19 Hospital during December 2020 using google form. Pilot study was done on 30 doctors of another COVID-19 hospital to know the average time required for completing the questionnaire on google form and to ensure that it is appropriate and understandable to participants. Necessary 
amendments were done in questionnaire on the basis of feedback obtained from pilot study. Participants were recruited by contacts obtained from Duty roster of COVID-19.Participants were approached through WhatsApp message and asked to give their response through link provided.

\section{Statistical Analysis}

The analysis was done using IBM-SPSS software20.

\section{Ethical Considerations}

The study was approved by the institute ethical committee. The purpose of the study was explained to the students and the participation was entirely voluntary. Informed consent was obtained from the participants.

\section{Results}

A total of $219 \mathrm{HCW}$ sarticipated in the study where $58.0 \%$ were women and 42.0 were gentlemen. $21.9 \%$ was faculty, $30.6 \%$ were resident doctors and $47.5 \%$ were nursing staff. The characteristics of the participants are shown in Table $1.90 \%$ of the respondents feared contracting COVID-19 infection, and 97\% feared carrying the infection home. $80 \%$ respondents felt that they were not welcomed by their community.

Table 1 Gender distribution, designation and specialty of participants

\begin{tabular}{|l|l|}
\hline Gender & Female 127(58.0\%) \\
& Male 92(42.0\%) \\
\hline Designation & Faculty 41(21.9\%) \\
& Residents 67(30.6\%) \\
& Nursing officer 104(47.5\%) \\
\hline Specialty & Anesthesiologist 23(10.5\%) \\
& Surgeon 14 (6.4\%) \\
& Physician 23 (10.5\%) \\
& Obstetrician 03 (1.4\%) \\
& Doctor from other specialty 52(23.7\%) \\
& Nursing officer 104 (47.5\%) \\
\hline
\end{tabular}

Table 2 Psychological impact on HCWs

\begin{tabular}{|l|c|c|c|c|c|}
\hline & $\begin{array}{c}\text { Strongly } \\
\text { Agree (\%) }\end{array}$ & Agree (\%) & $\begin{array}{c}\text { Neither agree } \\
\text { nor disagree } \\
(\%)\end{array}$ & Disagree (\%) & $\begin{array}{c}\text { Strongly } \\
\text { disagree (\%) }\end{array}$ \\
\hline $\begin{array}{l}\text { Increased burnout due to } \\
\text { pandemic }\end{array}$ & $82(37.4)$ & $105(47.9)$ & $26(11.9)$ & $6(2.7)$ & $82(37.4)$ \\
\hline $\begin{array}{l}\text { Increased physiological } \\
\text { stress due to pandemic }\end{array}$ & $93(42.5)$ & $98(44.7)$ & $8(3.7)$ & $19(8.7)$ & $1(0.5)$ \\
\hline
\end{tabular}

Table 3 Fears and worries of HCWs

\begin{tabular}{|l|c|c|c|c|c|}
\hline & $\begin{array}{c}\text { Strongly } \\
\text { agree }(\%)\end{array}$ & $\begin{array}{c}\text { Agree } \\
(\%)\end{array}$ & $\begin{array}{c}\text { Neither agree nor } \\
\text { Disagree }(\%)\end{array}$ & $\begin{array}{c}\text { Disagree } \\
(\%)\end{array}$ & $\begin{array}{c}\text { Strongly } \\
\text { disagree }(\%)\end{array}$ \\
\hline High risk of exposure during duty & $81(37)$ & $103(47)$ & $20(9.1)$ & $15(6.8)$ & 0 \\
\hline $\begin{array}{l}\text { May transmit infection to family } \\
\text { members }\end{array}$ & $128(56.2)$ & $88(40.2)$ & $4(1.8)$ & $4(1.8)$ & 0 \\
\hline $\begin{array}{l}\text { Can be infected even after following } \\
\text { guidelines }\end{array}$ & $71(32.4)$ & $124(56.6)$ & $4(1.8)$ & $20(9.1)$ & 00 \\
\hline
\end{tabular}




\section{JMSCR Vol||09||Issue||04||Page 58-64||April}

Table 4 Perception of HCWs

\begin{tabular}{|l|c|c|c|c|c|}
\hline & $\begin{array}{c}\text { Strongly } \\
\text { agree }(\%)\end{array}$ & Agree (\%) & $\begin{array}{c}\text { Neither agree } \\
\text { nor disagree } \\
(\%)\end{array}$ & $\begin{array}{c}\text { Disagree } \\
(\%)\end{array}$ & $\begin{array}{c}\text { Strongly } \\
\text { Disagree } \\
(\%)\end{array}$ \\
\hline $\begin{array}{l}\text { Training reduces chances of } \\
\text { infection }\end{array}$ & $77(35.2)$ & $134(61.2)$ & $6(2.7)$ & $2(0.9)$ & 00 \\
\hline $\begin{array}{l}\text { Public health sector aloneisnot } \\
\text { sufficient }\end{array}$ & $58(26.5)$ & $118(53.9)$ & $17(7.8)$ & $16(7.3)$ & $10(4.6)$ \\
\hline $\begin{array}{l}\text { Increasing workforce will help in } \\
\text { effective control of pandemic }\end{array}$ & $59(26.9)$ & $127(58)$ & $18(8.2)$ & $15(6.8)$ & 00 \\
\hline $\begin{array}{l}\text { COVID-19 will have long lasting } \\
\text { effects on HCWs }\end{array}$ & $71(32.4)$ & $120(54.8)$ & $25(11.4)$ & $3(1.4)$ & 00 \\
\hline $\begin{array}{l}\text { Public health experts should be } \\
\text { part of policy making }\end{array}$ & $82(37.4)$ & $119(54.3)$ & $12(5.5)$ & $3(1.4)$ & $3(1.4)$ \\
\hline
\end{tabular}

Table 5 Challenges with patient management

\begin{tabular}{|l|c|c|c|c|c|}
\hline & $\begin{array}{c}\text { Strongly } \\
\text { agree (\%) }\end{array}$ & Agree (\%) & $\begin{array}{c}\text { Neither agree } \\
\text { nor disagree } \\
(\%)\end{array}$ & $\begin{array}{c}\text { Disagree } \\
(\%)\end{array}$ & $\begin{array}{c}\text { Strongly } \\
\text { disagree }(\%)\end{array}$ \\
\hline $\begin{array}{l}\text { Increased workload hampers } \\
\text { treating serious patients }\end{array}$ & $53(24.2)$ & $116(53.0)$ & $27(12.3)$ & $23(10.5)$ & 00 \\
\hline $\begin{array}{l}\text { No attendant policy is a } \\
\text { barrier to communication }\end{array}$ & $48(21.9)$ & $107(48.9)$ & $33(15.1)$ & $30(13.7)$ & $1(0.5)$ \\
\hline $\begin{array}{l}\text { Non-Covid patients are } \\
\text { notgetting appropriate } \\
\text { attention }\end{array}$ & $86(39.3)$ & $99(45.2)$ & $20(9.1)$ & $13(5.9)$ & $1(0.5)$ \\
\hline $\begin{array}{l}\text { Patients are satisfied with } \\
\text { advice on telephone }\end{array}$ & $12(5.5)$ & $78(35.6)$ & $62(28.3)$ & $65(29.7)$ & $2(0.9)$ \\
\hline
\end{tabular}

Majority (85.3\%) of participants accepted increased burnout during their duty and $87.2 \%$ respondents felt increased psychological stress (table 2).

$84 \%$ of respondents thought that they may get infected due to their nature of job of caring COVID-19 patients. Almost all (96.4\%) were concerned regarding carrying infection to their family members and loved ones. $89 \%$ of respondents worry that even after following proper guidelines they may become infected (table $3)$.

\section{Discussion}

The findings from the present study showed that frontline medical staff experienced emotional stress during the COVID- 19 outbreak, which has been supported by previous studies on other epidemics, although their extent differs. ${ }^{\mathbf{8} 9}$ In our study we found that there is increased burnout (94\%), increased psychological stress $(93.5 \%)$ and disrupted routine life (99\%)due to pandemic among HCWs on COVID-19 duty. Ruchira et al also found a high prevalence of burnout during the current pandemic compared to pre-COVID-19 era. ${ }^{10}$ Burnout in HCWs, particularly doctors have been shown to cause increased medical errors. ${ }^{11}$ It can lead to decreased patient satisfaction and thus increases the chances of litigation. Burnout among HCWs is multifactorial and has been shown to cause various detrimental effects as during SARSa questionnaire-based survey in the staff working in the EDs, revealed a significantly high distress levels in the nursing staff, doctors, and healthcare assistants in decreasing trend, in that order. ${ }^{\mathbf{1 2}}$ The psychological stress for HCWs working during pandemic has been attributed to various factors such as possibility of quarantine, fear of infections due to contagious nature of disease, concern for self and family, job stress, interpersonal isolation, perceived stigma, fear of doing unfamiliar work (for non-ICU/ED HCWs), etc. ${ }^{13}$ Previous studies have indicated that nurses suffering job burnout are more likely to be dissatisfied with their jobs and to look for opportunities to leave their jobs (Dyrbye et al. 2019). ${ }^{14}$ There have been plenty of 
reports from china detailing the number of HCWs getting infected and even succumbing to the illness. ${ }^{15}$ Despite serving patients of COVID-19 and risking their life, healthcare workers were treated very badly while on duty and also in society. They were asked to vacate their rented homes. HCWs became new untouchable as people believed that HCWs are spreading the disease due to their nature of job. Even funeral of HCWs died during care of COVID-19 patients was opposed by some local people. So, it is the duty of administration to provide security to medical fraternity and punish the culprits so that health workers can work stress free in this pandemic. Special insurance and health package can be awarded to provide sense of security to health care providers. Organizational leaders should provide clear messages that clinicians are valued and that managing the pandemic together is the goal. ${ }^{\mathbf{1 6}} \mathrm{Our}$ studies shows that majority $(84 \%)$ of HCWs thought that there is a high risk of infection during care of COVID-19 patients and $96.4 \%$ felt that they can transmit infection to their family members (Table 3). This is in line with the study done be Yongfang Jiang et al who noticed in their study that All doctors showed concern for carrying the disease to their families and expected support from seniors and administration, leaders should aim to monitor clinician wellness and proactively address concerns related to the safety of clinicians and their families. ${ }^{17}$ Almutairi et al. (2018) also found in their study that during the outbreaks of SARS and MERS, the HCWs reported concerns about themselves and their families' health and explained their painful experiences of fear, anxiety, and even social prejudice and stigma. ${ }^{18}$ GOVT. OF INDIA has taken various steps to safeguard the rights and protection of HCWs and their dependents. The Ministry of Health has approved a new category for selection and nomination of candidates from 'Wards of COVID Warriors' under Central pool MBBS/BDS seats for the academic year 2020-21, throwing flower petals on HCWs addressing them as CORONA WORRIERS. Recognition and appreciation of the work and efforts by the medical profession, hospital management, government, and society have a positive impact onstress experienced by medical staff during epidemics. ${ }^{\mathbf{8}}$ Healthcare workers rely on personal protective equipment to protect themselves and their patients from being infected and infecting others. In our study $96.4 \%$ respondents opine that training reduces chances of infection, Robound $j$ et al also found in their study that Infection control training was strongly associated with a decrease in the severe acute respiratory syndrome coronavirus (SARS-CoV) healthcare provider infection rate, ${ }^{19}$ and, by extension, the same can be expected for SARS-CoV-2 infection rate. Due to limited access to supplies such as gloves, N -95 face masks, respirators, goggles, face shields, gowns, and aprons will make health care providers more prone for infection. Tsamakis et al in their commentwrote that the wrong use of protective equipment causes difficulties in breathing and limited access to toilet and water, resulting in subsequent physical and mental fatigue. ${ }^{20}$ So adequate staff training, adequate and ample supply of PPE and proper guidance are required to control infections and limit deaths in health care workers. Healthcare workers have been facing treatment related dilemmas every day starting from Initial assessments in OPD to serious ill patient requiring ICU care. It has been found in many studies that due to COVID-19, patients with other illness are not getting proper attention. In our study we found that $84.5 \%$ participants agree this issue (table 5). It may be due to fear of infection and hundreds of guidelines issued by different specialties for managing respective patients. HCWs are in a state of incertitude to follow or ignore these guidelines as long-term effects of lasting newly formed recommendations are not known. The significant impact of COVID19 has created an opportunity for health system to evolve in new ways and rapidly adapt to new normal. This pandemic has shed light on the importance of ample investing in health care sector. 


\section{Conclusion}

The COVID-19 pandemic is straining health systems worldwide. It exposed the poor health system all over the world and impacted healthcare workers badly in all aspects. Few noticeable issues raised by this study are: Insufficient and limited resources, potential disease exposure, rapidly changing clinical practices, concern for personal, family and client safety, and psychological impact on frontline workers. Finding of this study reveal various areas which need improvement to tackle the scenario more efficiently as well as safeguarding health of healthcare workers, workforce protection, support and sustainability.

\section{Recommendations}

There is an urgent and towering need for drastic restructuring of our health care system. We feel reducing the burden on HCWs, Provision of Adequate PPE and Work distribution among existing resources. Government should introduce stress management workshops and counseling in health sector and it should be conducted at a regular interval. Involvement of Private Practitioners in Public Health setups when in need and to include Doctors particularly Public Health experts in policy making in such scenario to expect better outcome.

\section{Strengths of the Survey}

This is one of the few investigations specially exploring challenges faced by HVWs on duty during care of COVID-19 patients and provides an important insight about concern of HCWs on duty. The work presented here has profound implications on future studies on the challenges faced by healthcare workers particularly during pandemic or other health crisis situation. The present study will certainly help researchers in drawing the attention of policy makers to think and act regarding issues of healthcare workers as well.

\section{Limitation of the Survey}

We included doctors of only one COIVID-19 hospital in the survey so the findings cannot be generalized. Given this unprecedented context, these data represent a snapshot of a single point in time, as such don't capture changes arising from the evolving pandemic response. Recruitment via asocial media may exclude doctors not present on theses platforms and impact the representative sample. The study analyzed only few variables related to challenges faced by doctors, but there may be additional influential variables, accordingly further researches should be devoted to find this knowledge gap.

Conflicts of interest: There are no conflicts of interest.

\section{References}

1. Urooj U, Ansari A, Siraj A, Khan S, Tariq H. Expectations, Fears and Perceptions of doctors during Covid-19 Pandemic. Pak J MedSci.2020;36(COVID19-

S4):COVID19-S37-S42

2. Situation Report-67 SITUATION IN NUMBERS total and new cases in last 24hours, WHO.

3. WHO director-general's opening remarks at the media briefing on COVID-19 3March2020.

4. WHO Director-General's opening remarks at the media briefing on COVID-19 - 11 March 2020.

5. High proportion of healthcare workers with COVID-19 in Italy www.icn.ch , news $>$ high- proportion-healthcare worker.

6. COVID-19 Related Deaths among Doctors in India, Aanandita Kapoor, Krishan Mohan Kapoor, COVID-19 SARS-CoV-2 preprints from medRxiv and bioRxiv.

7. Malta MVSC. Mobidoctor Malta VS COVID19-The war is on! MVSC Maltamobidoctor.eu

8. Khalid I, Khalid TJ, Qabajah MR et al: Healthcare workers emotions, peraceived 
stressors and coping strategies during a MERS CoV outbreak. Clin Med Res, 2016; 14(1): 7 - 14.

9. Koh D, Lim MK, Chia SE et al: Risk perception and impact of Severe Acute Respiratory Syndrome (SARS) on work and personal lives of healthcare workers in Singapore: what can we learn? Med Care, 2005; 43(7): 676 - 82 .

10. Ruchira W Khasne, Bhagyashree S Dhakulkar, Hitendra C Mahajan and Atul P Kulkarni. Burnout among Healthcare Workers during COVID-19 Pandemic in India: Results of a Questionnaire-based Survey. Indian J Crit Care Med. 2020 Aug; 24(8): 664-671.

11. Shanafelt TD, Balch CM, Bechamps G, Russell T, Dyrbye L, Satele D, et al. Burnout and medical errors among American surgeons. Ann Surg. 2010; 251(6):995-1000.

12. Wong TW, Yau JKY, Chan CLW, Kwong RSY, Ho SMY, Lau CC, et al. The psychological impact of severe acute respiratory syndrome outbreak on healthcare workers in emergency departments and how they cope. Eur J Emerg Med. 2005;12(1):13-18.

13. Maunder R, Lancee W, Balderson K, Bennett J, Borgundvaag B, Evans S, et al. Long-term psychological and occupational effects of providing hospital healthcare during SARS outbreak. Emerg Infect Dis. 2006;12(12):1924-1932.

14. Dyrbye LN, Shanafelt TD, Johnson PO, Johnson LA, Satele D, West CP (2019) A cross-sectional study exploring the relationship between burnout, absenteeism, and job performance among American nurses. BMC Nurs 18:57.

15. Wu P, Fang Y, Guan Z, et al. The psychological impact of the SARS epidemic on hospital employees in China: exposure, risk perception, and altruistic acceptance of risk. Can J Psychiatry 2009; 54(5): 302-311.

16. Heymann DL, Shindo N. COVID-19: what is next for public health? Lancet. 2020;395(10224):542-545. doi: 10.1016/ S0140-6736(20)30374-3

17. Jiang Y. Psychological Impact and Coping Strategies of Frontline Medical Staff in Hunan between January and March 2020 During the Outbreak of Coronavirus Disease 2019 (COVID-19) in Hubei, China. Med Sci Monit. 2020;26:e924171.

18. Jiang Y. Psychological Impact and Coping Strategies of Frontline Medical Staff in Hunan between January and March 2020 During the Outbreak of Coronavirus Disease 2019 (COVID-19) in Hubei, China. Med Sci Monit. 2020;26: e924171.

19. Raboud J, Shigayeva A, McGeer A, et al. Risk factors for SARS transmission from patients requiring intubation: a multicentreinvestigation in Toronto. Canada. PLoS One. 2010.

20. Tsamakis K, Rizos E, Manolis AJ, Chaidou S, Kympouropoulos S, Spartalis E, Spandidos DA, Tsiptsios D, Triantafyllis AS. [Comment] COVID-19 pandemic and its impact on mental health of healthcare professionals. Experimental and Therapeutic Medicine 2020; 19:34513. 